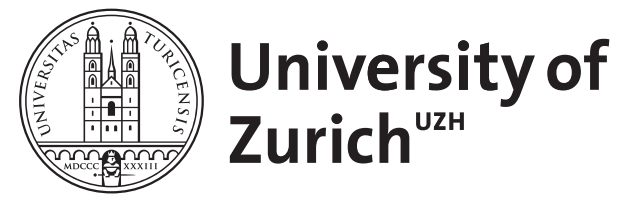

Zurich Open Repository and Archive

University of Zurich

University Library

Strickhofstrasse 39

CH-8057 Zurich

www.zora.uzh.ch

Year: 1992

\title{
Manuscript of the Quedlinburg Cathedral back in Germany
}

Siehr, Kurt

DOI: https://doi.org/10.1017/s0940739192000195

Posted at the Zurich Open Repository and Archive, University of Zurich

ZORA URL: https://doi.org/10.5167/uzh-154934

Journal Article

Published Version

Originally published at:

Siehr, Kurt (1992). Manuscript of the Quedlinburg Cathedral back in Germany. International Journal of Cultural Property, 1(01):215.

DOI: https://doi.org/10.1017/s0940739192000195 


\section{Manuscript of the Quedlinburg Cathedral back in Germany}

\section{Kurt Siehr*}

A year ago very few people outside Germany knew of a place called Quedlinburg, a small town in East Germany (Saxony-Anhalt), close to the former German-German border. This ignorance changed last spring when it became public that a German foundation (Kulturstiftung der Laender) and the Federal Ministry of Internal Affairs purchased back the Samuhel manuscript, part of the treasure of Quedlinburg Cathedral which was stolen in 1945 by an American soldier. This alone does not explain the importance of this purchase.

The manuscript is not only one of the few Carolingian preciously bound and decorated bibles of the tenth century of Southern German origin. It is also a valuable piece of national cultural property insofar as Quedlinburg is one of those places of early German history where, under the reign of Saxon kings and emperors, spiritual and artistic life flourished before and after the year 1000. It was in Quedlinburg that in 936 Otto I, Duke of Saxony, King of Germany and Emperor of the Holy Roman Empire, married Editha, the daughter of Aethelstan, the West Saxon King of the English and grandson of Alfred the Great. Here Mathilde, widow of the German King Henry $I$ and mother of Otto $I$, and one of the important female figures of the German Middle Ages, promoted the building of the Cathedral. She was the good spirit of one of the most important centres of Saxony and Northern Europe in her time. The Samuhel manuscript (written by a monk of that name) was donated to Mathilde for the Cathedral and remained in Quedlinburg until 1945.

Quedlinburg was taken by the Western allied forces in 1945 before it became part of the Soviet-occupied zone of Germany. The treasure of the Quedlinburg Cathedral, including the Samuhel manuscript, was missed very early and its whereabouts remained unknown.

As it turned out later the treasure had been stolen by the American Army officer Jack T. Meador (1916-1980). Jack T. Meador, having majored in art at the North Texas State University, lived in Whitewright, Texas, after being discharged in 1946. He taught art at a school and ran a hardware and farm equipment business founded by his father. He kept the treasure throughout his life.

Some years after his death, Mr Meador's heirs wanted to sell the manuscript. Some museums, collectors and auction houses seem to

* Professor Dr. jur. M.C. L., University of Zurich Centrum for IPR. 


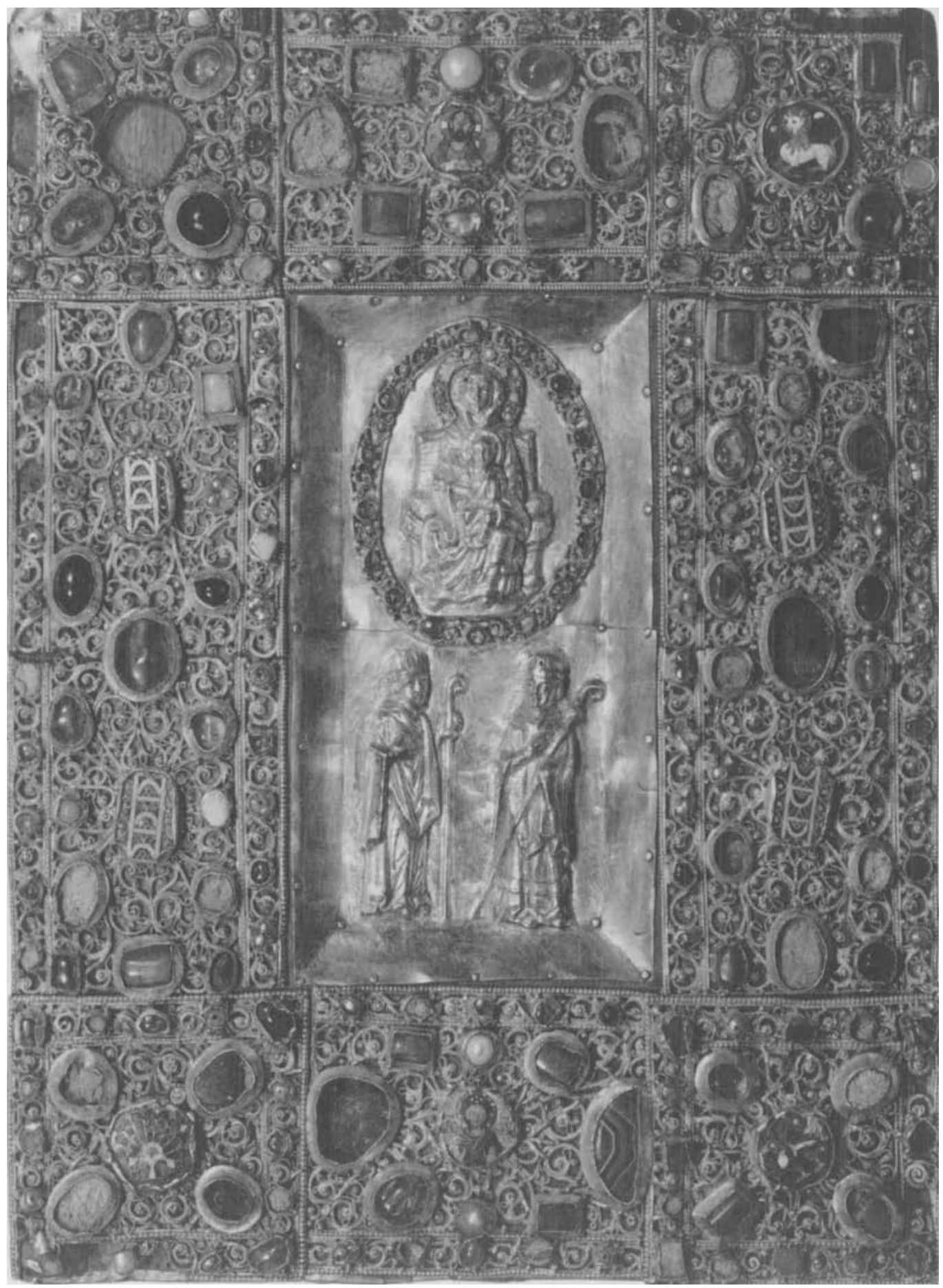

The magnificent cover of the Quedlinburg bible. Photo: Jutta Brüdern, Braunschweig 
have declined to have anything to do with the manuscript because of its stigma as stolen cultural property. Therefore contacts were arranged with West German cultural officials and their representatives and agents. Finally the manuscript was acquired by West German institutions (Federal Ministry of Internal Affairs, Cultural Foundation of German States) for US $\$ 3 \mathrm{~m}$. After restoration in Munich, the manuscript was exhibited from January 17 - February 171991 in the Bavarian State Library in Munich and described in a Catalogue edited by the Cultural Foundation of German States and by the Ernst von Siemens Foundation. The manuscript will be exhibited permanently at its home as soon as safe and accessible treasure rooms are ready in Quedlinburg. 
Downloaded from https:/www.cambridge.org/core. University of Basel Library, on 11 Jul 2017 at 14:37:21, subject to the Cambridge Core terms of use, available at https:/www.cambridge.org/core/terms. https://doi.org/10.1017/S0940739192000195 